\title{
SUPPLYING AND DECOMPOSITION OF BURLAP IN A FRAGMENT OF CERRADO SENSU STRICTO
}

\author{
Carolina Medinilla Pedro ${ }^{1 *}$, Francisca de Cássia S. da Silva ${ }^{1 *}$, Antonio Carlos Batista² $^{2}$ Marcelo Ribeiro \\ Viola $^{3}$, Maria Cristina Bueno Coelho' ${ }^{1}$, Marcos Giongo \\ ${ }^{1 *}$ Federal University of Tocantins, Environmental Monitoring and Fire Management Center (CeMAF), Gurupi, State of Tocantins, \\ Brazil - *carolme1991@gmail.com,*cassia96silva@gmail.com, mariacristina@mail.uft.edu.br, giongo@uft.edu.br \\ ${ }^{2}$ Federal University of Paraná, Forest Engineering Department, Curitiba, State of Paraná, Brazil - batistaufpr@gmail.com \\ ${ }^{3}$ Federal University of Lavras, Forest Engineering Department, Lavras, State of Minas Gerais, Brazil - marcelo.viola@ deg.ufla.br
}

Received to publication: 16/12/2017 - Accepted to publication: 25/07/2018

\begin{abstract}
Considering the importance of nutrient cycling as an indicator in the maintenance of the ecosystem productivity, the present study aimed to assess the seasonal dynamics of production and decomposition rate of litter in a fragment of Cerrado sensu stricto. The litter collections were carried out monthly from june 2016 to may 2017, after which the leaves, branches and reproductive material were separated. The litter decomposition was evaluated using the litter bags method, with a random distribution of 288 litter bags. The annual production of litterfall was quantified in $6.042,50 \mathrm{~kg} \cdot \mathrm{ha}^{-1} \cdot \mathrm{yr}^{-1}$, in which the leaf prevalent fraction presented a production of $4.644,40 \mathrm{~kg} \cdot \mathrm{ha}^{-1} \cdot \mathrm{yr}^{-1}$, then, the fractions branches $\left(1.084,10 \mathrm{~kg} \cdot \mathrm{ha}^{-1} \cdot \mathrm{yr}^{-1}\right)$ and reproductive material $(329,90$ $\left.\mathrm{kg} \cdot \mathrm{ha}^{-1} \cdot \mathrm{yr}^{-1}\right)$. The litterfall obtained higher production in july with $1.464,00 \mathrm{~kg}^{-h^{-1}}$ and lower production in the month of December (138,70 kg.ha-1 $)$. A significant negative correlation was observed between litterfall and its fractions with the precipitation and relative humidity. The decomposition of foliar mass reached $49 \%$ and $50 \%$ of twigs during the nine-month period, in which the decomposition constant (k) for leaf mass and for branches was $0.0030 \mathrm{~g} \mathrm{~g}^{-1} \mathrm{day}^{-1}$. For this constant, the estimate for the disappearance of total mass has been estimated to be 1.000 days ( 29 months). The breakdown proved to be slow for both leaves and branches thus obtaining the value of the constant of decomposition $0.0030 \mathrm{~g} \mathrm{~g}^{-1}$ day $^{-1}$ for both.

Keywords: Production, dynamics, correlation.
\end{abstract}

\section{Resumo}

Fornecimento e decomposição de serapilheira em um fragmento de Cerrado sensu stricto. Considerando a importância da ciclagem de nutrientes como indicador na manutenção da produtividade do ecossistema, o presente estudo teve como objetivo avaliar a dinâmica sazonal de produção e taxa de decomposição de serapilheira em um fragmento de Cerrado sensu stricto. As coletas de serapilheira foram realizadas mensalmente de junho de 2016 a maio 2017, posteriormente foi realizada a separação nas frações folhas, galhos e material reprodutivo. A decomposição da serapilheira foi avaliada utilizando o método de litter bags, com distribuição aleatória de 288 litter bags. A produção anual de serapilheira foi quantificada em $6.042,50 \mathrm{~kg}$.ha${ }^{1} \cdot \mathrm{a}^{-1}$, em que a fração foliar foi predominante apresentando produção de $4.644,40 \mathrm{~kg} \cdot \mathrm{ha}^{-1} \cdot \mathrm{a}^{-1}$, seguida da fração galhos $\left(1.084,10 \mathrm{~kg} \cdot \mathrm{ha}^{-1} \cdot \mathrm{a}^{-1}\right)$ e material reprodutivo $\left(329,90 \mathrm{~kg} \cdot \mathrm{ha}^{-1} \cdot \mathrm{a}^{-1}\right)$. A produção de serapilheira obteve maior produção no mês de julho com $1.464,00 \mathrm{~kg} \cdot \mathrm{ha}^{-1}$ e menor produção no mês de dezembro $\left(138,70 \mathrm{~kg} \cdot \mathrm{ha}^{-}\right.$ $\left.{ }^{1}\right)$. Foi observada correlação negativa significativa entre a produção de serapilheira e suas frações com a precipitação pluviométrica e umidade relativa do ar. A decomposição da massa foliar atingiu $49 \%$ e a de galhos $50 \%$ durante o período de nove meses, em que a constante de decomposição (k) para massa foliar e para galhos foi de $0,0030 \mathrm{~g} \mathrm{~g}^{-1} \mathrm{dia}^{-1}$. Por esta constante, a estimativa para o desaparecimento de massa total foi estimada em 1.000 dias (29 meses). A decomposição se mostrou lenta tanto para folhas como para galhos obtendo, assim, o valor da constante de decomposição $0,0030 \mathrm{~g} \mathrm{~g}^{-1} \mathrm{dia}^{-1}$ para ambos.

Palavras-chave: Produção, dinâmica, correlação.

\section{INTRODUCTION}

Brazil has the largest savanna area in the world, being the second largest Brazilian biome (occupying $21 \%$ of the national territory) and presenting vegetation with varied phytophysiognomies (MYERS et al., 2000). Cerrado is recognized as the world's richest savanna, considered one of the hot spots for planet's biodiversity 
preservation due to its high biological diversity, high degree of endemism and its low level of protection (MYERS et al., 2000).

The productivity of an ecosystem depends on the amount of nutrients stored in its various compartments, such as vegetation, litter, soil and animal biomass, as well as the rate of transfer (SILVA et al., 2007). The litter is composed of several types of plant material deposited on the soil surface (leaves, bark, branches, trunks, twigs, flowers, inflorescences, fruits, seeds and other plant fragments) and its production represents the first stage of nutrient transfer to the soil, which are removed by the plants (CALDEIRA et al., 2008).

In this direction, the litter assumes an important role in nutrients cycling, therefore the organic material that is deposited continuously on the ground is basic for fertility maintenance (CALVI et al., 2009). However, the concentration of the nutrients can vary in function of the floristic groups, the species and the plants' characteristics, in which the amount of nutrients returned to the ground can be proportional to the litter production, depending on the amount of material (LONGHI et al., 2011).

As plants periodically replace their vegetative and reproductive structures in response to the climate, the collection and quantification of these materials deposited on the soil represents a nondestructive way to estimate the productivity of litter in different ecosystems. Several biotic and abiotic factors influence litter production, such as vegetation type, herbivory, altitude, latitude, precipitation, temperature, light availability during the growing season, photoperiod, evapotranspiration, relief, slope, successional stage, water availability and soil characteristics. In this sense, the interactions between these factors define their production, with one of them prevailing over the others, which varies according to the characteristics of each ecosystem (CALVI et al., 2009).

In relation to litter decomposition, the leaf fraction is the one that contributes most to the returning of nutrients to the soil according to studies carried out by Teo et al. (2010) in the state of Paraná with legumes and Caldeira et al. (2013) in the state of Espirito Santo. In contrast Costa et al. (2014), in their research in the Amazonian biome, found out the highest concentration of nutrients in the stem. In this sense, regarding the rate of decomposition, variation occurs among the different ecosystems according to biotic and abiotic factors (CALVI et al., 2009; LIMA et al., 2015; SANCHES et al., 2009).

Thus, for Sanches et al. (2009), cycling process has great importance not only for understanding ecosystems' functioning, but also for the generation of subsidies for forest management, as well as for the detection of disturbances of natural and anthropogenic origins. Thus, in the light of the above, this research had as objective to evaluate the seasonal dynamics of production and the rate of decomposition of litter in a fragment of Cerrado sensu stricto.

\section{MATERIAL AND METHODS}

\section{Study area characterization}

This study was developed at CeMAF Experimental Station (EEC), located at the Federal University of Tocantins (UFT) in Gurupi, state of Tocantins $\left(11^{\circ} 46^{\prime} \mathrm{S}\right.$ and $\left.49^{\circ} 02^{\prime} \mathrm{W}\right)$, and according to the Thornthwaite climate classification, the climate in the study region is C2wA'a", characterized as subhumid wetness and moderate water deficiency in the winter, with an average potential annual evapotranspiration of 1,500 mm, distributed in summer around $420 \mathrm{~mm}$ over the three consecutive months with a higher temperature (CAMPOLINA et al., 2012). Data on temperature, relative humidity and precipitation (Figure 1) were obtained from the Meteorological Station of the Federal University of Tocantins, Campus of Gurupi-TO.

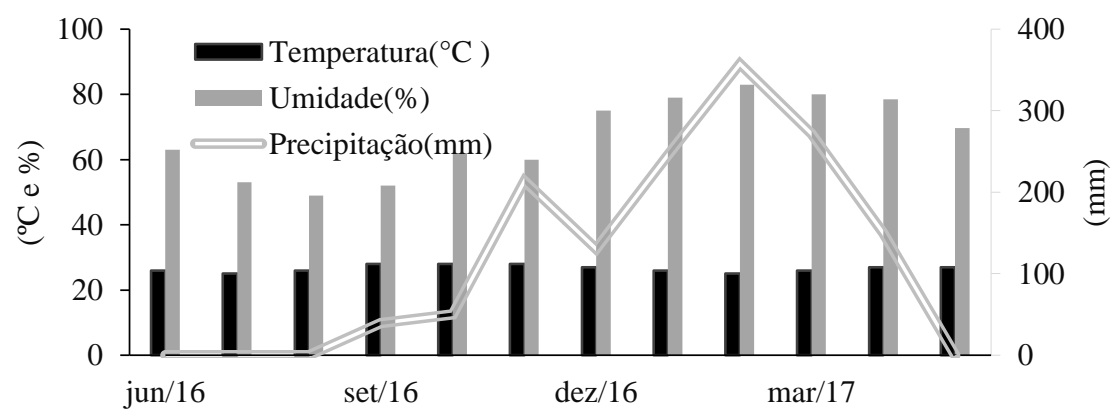

Figure 1. Temperature average monthly, accumulated monthly rainfall and relative humidity of the air from june 2016 to may 2017. 
Figura 1. Temperatura média mensal, precipitação acumulada mensal e umidade relativa do ar no período de junho de 2016 a maio de 2017.

The phytophysiognomy present in the study area is Cerrado sensu stricto type and typical Cerrado subtype according to the classification of Ribeiro and Walter (1998), because it presents predominantly shrubby-arboreal vegetation of average height, about three to six meters. It is also observed in the area an advanced stage of regeneration with small diameters and the presence of lianas (vines).

The soil present in the study area is classified as plinthosols, which are mineral soils that present plintic, litoplíntic or concrete horizon. The plinthite is formed by the mixture of clay with quartz grains and other minerals, with moderate carbon and a lot of iron and aluminum, which in several periods of humidity and drying are irreversibly consolidated (EMBRAPA, 2013).

\section{Experiment design}

The experiment was set up systematically, and five transects were demarcated, in which 10 circular collectors with a distance of 10 meters were installed along each other, totaling 50 collectors and $50 \mathrm{~m}$ of area (Figure 2), with the collection being performed monthly and started in june 2016 and ended in may 2017.
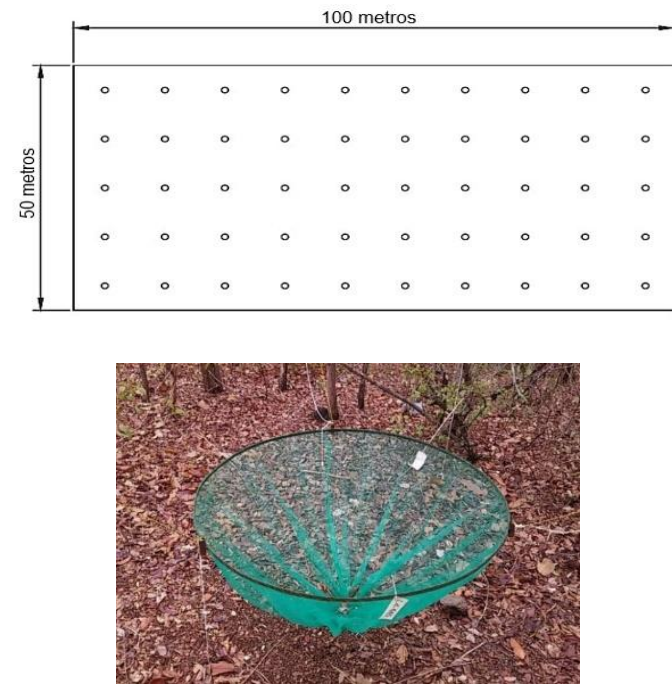

Figure 2. Disposition of collectors in the study area and circular collector illustration. Figura 2. Disposição dos coletores na área de estudo e ilustração do coletor circular.

The suplying of litter was determined by the use of the collectors, which consisted of a circular metal frame with $112.8 \mathrm{~cm}$ in diameter equivalent to $1 \mathrm{~m}^{2}$ (Figure 3), in the metal area a nylon screen was sewn with mesh of $2 \mathrm{~mm}$, forming a conical bag of approximately $50 \mathrm{~cm}$ depth, for the accumulation of litter and facilitate the exit of water. The frames were set in trees approximately $50 \mathrm{~cm}$ high from the ground.

In each collection, the litter was packed in plastic bags, then transported to the laboratory for sorting the fractions: leaves (leaflets and petioles), branches (corresponding to woody and arboreal parts of all dimensions) and reproductive material (seeds, flowers and fruits). After sorting, the fractions were conditioned in identified paper bags, put to dry in a forced circulation oven at $70^{\circ} \mathrm{C}$ for 48 hours and then weighed in a precision scale.

The annual litter production, in $\mathrm{kg} \cdot \mathrm{ha}^{-1}$, was estimated based on the equation:

$$
\mathrm{PS}=(\Sigma \mathrm{PM} \times 10.000) / \mathrm{Ac}
$$

In which: PS = Litter production $\left(\mathrm{kg} \cdot \mathrm{ha}^{-1} \cdot \mathrm{year}^{-1}\right), \mathrm{MW}=$ Monthly litter production $\left(\mathrm{kg} \cdot \mathrm{ha}^{-1} \cdot \mathrm{month}^{-1}\right)$ and $\mathrm{Ac}=$ Collector area $\left(\mathrm{m}^{2}\right)$.

The litter decomposition rate was estimated by the mass loss method through litter bags, made with $2 \mathrm{~mm}$ nylon mesh with $25 \times 25 \mathrm{~cm}$ of size. Twenty grams from the first collection were deposited on each litter bag, so that 288 litter bags contained leaves and 24 branches. These were distributed randomly near the collectors and in direct contact with the surface of the soil on september 30, 2016.

The collections of litter bags with leaves were carried out biweekly, and in each period 12 bags were removed, while the litter bags collections with branches were carried out monthly, with two pockets of 
decomposition being removed in each period. The collections of litter bags were carried out in the period from october 2016 to june 2017.

After collection, litter bags were sent to the laboratory where they were opened and cleaned with the aid of brush and sieve, removing materials not coming from the samples placed inside the litter bags. Subsequently, the samples were packed in paper bags and dried in an oven at $70^{\circ} \mathrm{C}$ until reaching the constant weight and then weighed in an analytical precision scale to obtain the remaining mass.

The estimate of litter decomposition rate was estimated by mass loss measurement evaluations, by the following equation:

$$
\text { Mass remaining }(\%)=\frac{\text { mass last }}{\text { mass initial }} \times 100
$$

The coefficients of decomposition $(\mathrm{k})$ of the leaves and branches fraction over the study months were obtained by fitting the exponential model, according to Terror et al. (2011):

$$
X t=X 0 . e^{-k t}
$$

In which $\mathrm{Xt}=$ dry weight of the remaining material after $\mathrm{t}$ days, $\mathrm{X} 0=$ initial weight of dry material placed on bags at time zero $(\mathrm{t}=0), \mathrm{k}$ : decomposition constant and $\mathrm{t}=$ time in days.

The following equation was used to calculate the time required for the decomposition of $95 \%$ of the residue (leaves and branches):

$$
T 95 \%=3 / \mathrm{k}
$$

$\mathrm{k}=$ decomposition constant calculated by the above formula $\left(\mathrm{Xt}=\mathrm{X} 0 . \mathrm{e}^{-\mathrm{kt}}\right)$.

\section{Statistical analysis}

Data were tabulated in Excel spreadsheets, analysis of variance (ANOVA) was carried out and the ScootKnott test was used at a 5\% probability level to compare the means. In order to evaluate the influence of the meteorological conditions on the litter production, Pearson's simple correlation ( $r$ ) between the monthly litter production and the meteorological variables was performed. For multiple regression analysis, the Stepwise method was used, taking into account the meteorological variables as dependent, with the selection of the best models made by the highest adjusted coefficient of determination $\left(\mathrm{R}^{2}\right)$ and the lowest standard error of the estimate $\left(\mathrm{S}_{\mathrm{yx}}\right)$.

\section{RESULTS}

\section{Litter Production}

The monthly litter production in the study area presented averages of 138.70 to $1.464 .0 \mathrm{~kg} \cdot \mathrm{ha}^{-1} \cdot \mathrm{month}^{-1}$, reaching an average annual production of $6,042.50 \mathrm{~kg} \cdot \mathrm{ha}^{-1} \cdot \mathrm{a}^{-1}$, composed of leaf fraction, branches (bark and branches) and reproductive material. Table 1 shows the monthly averages of litter production in its totality and fractions, the results obtained from the Scott-Knott (1974) comparison test show the statistical differences between the months of collection.

\begin{tabular}{|c|c|c|c|c|c|c|c|c|}
\hline Month/Year & Leaves & & Branches & & M.R. & & Total & \\
\hline June/2016 & $709.00 \pm 141.24$ & $\mathrm{C}$ & $102.50 \pm 40.66$ & A & $4.60 \pm 4.29$ & $\mathrm{C}$ & $816.10 \pm 167.70$ & $\mathrm{C}$ \\
\hline July/2016 & $1,328.80 \pm 182.02$ & A & $118.20 \pm 41.18$ & A & $17.10 \pm 6.93$ & $\mathrm{C}$ & $1,464.00 \pm 217.45$ & A \\
\hline August/2016 & $1.027,10 \pm 124.18$ & B & $87.80 \pm 38.27$ & A & $70.40 \pm 15.78$ & B & $1,185.30 \pm 101.20$ & B \\
\hline September/2016 & $502.80 \pm 82.79$ & $\mathrm{D}$ & $112.20 \pm 76.32$ & A & $98.20 \pm 38.09$ & A & $713.20 \pm 182.45$ & $\mathrm{C}$ \\
\hline October/2016 & $172.10 \pm 22.40$ & $\mathrm{~F}$ & $164.80 \pm 97.66$ & A & $71.40 \pm 39.24$ & B & $408.40 \pm 97.76$ & $\mathrm{D}$ \\
\hline November/2016 & $81.50 \pm 10.38$ & $\mathrm{~F}$ & $66.00 \pm 14.59$ & B & $22.40 \pm 15.76$ & $\mathrm{C}$ & $169.90 \pm 15.03$ & $\mathrm{E}$ \\
\hline December/2016 & $67.20 \pm 15.89$ & $\mathrm{~F}$ & $62.00 \pm 19.93$ & B & $15.90 \pm 5.11$ & $\mathrm{C}$ & $138.70 \pm 23.49$ & $\mathrm{E}$ \\
\hline January/2017 & $81.80 \pm 11.07$ & $\mathrm{~F}$ & $73.20 \pm 31.16$ & $\mathrm{~B}$ & $18.40 \pm 6.96$ & $\mathrm{C}$ & $173.40 \pm 38.49$ & $\mathrm{E}$ \\
\hline February/2017 & $76.60 \pm 21.87$ & $\mathrm{~F}$ & $93.80 \pm 53.86$ & A & $2.10 \pm 3.26$ & $\mathrm{C}$ & $163.10 \pm 50.97$ & $\mathrm{E}$ \\
\hline $\operatorname{March} / 2017$ & $179.60 \pm 49.29$ & $\mathrm{~F}$ & $143.60 \pm 35.85$ & A & $3.40 \pm 3.36$ & $\mathrm{C}$ & $326.60 \pm 48.02$ & $\mathrm{D}$ \\
\hline April/2017 & $126.10 \pm 27.41$ & $\mathrm{~F}$ & $22.20 \pm 8.58$ & $\mathrm{~B}$ & $3.10 \pm 4.84$ & $\mathrm{C}$ & $151.30 \pm 37.68$ & $\mathrm{E}$ \\
\hline May/2017 & $291.80 \pm 14.30$ & E & $67.80 \pm 15.83$ & $\mathrm{~B}$ & $2.90 \pm 4.83$ & $\mathrm{C}$ & $332.50 \pm 18.58$ & $\mathrm{D}$ \\
\hline Totals & $4,644.40(77 \%)$ & & \multicolumn{2}{|c|}{$1,084.10(18 \%)$} & $329.90(5 \%)$ & \multicolumn{3}{|c|}{$6,042.50(100 \%)$} \\
\hline Average & 387.03 & \multicolumn{3}{|c|}{97.34} & 27.49 & \multicolumn{3}{|c|}{503.54} \\
\hline $\mathrm{CV}(\%)$ & 21.12 & & \multicolumn{2}{|l|}{51.81} & 62.97 & \multicolumn{3}{|c|}{21.25} \\
\hline
\end{tabular}

Table 1. Average monthly litter production (total and fractions kg.ha-1 $\mathrm{month}^{-1}$ ).

Tabela 1. Produção média mensal de serapilheira (total e frações kg.ha-1 $\mathrm{mês}^{-1}$ ).

Legend: MR: Reproductive Material; Averages followed by the same letters in the column did not present significant differences among themselves by the Scott-Knott test $(\mathrm{p}<0.05)$ 
Table 2 shows a negative correlation between leaf production and litter production with precipitation $(\mathrm{r}=-$ $0.68 ; \mathrm{p}<0.05)$ and relative humidity $(\mathrm{r}=-0.74 ; \mathrm{r}=-0.78, \mathrm{p}<0.01)$, indicating the direct influence of these variables on leaf deposition and total litter. In relation to the deposition of reproductive material, negative correlation ( $\mathrm{r}=-$ $0.69, \mathrm{p}<0.05)$ with the relative humidity of the air was verified. There was no significant correlation between the contribution of litter and its fractions with temperature, which proves that there was no influence of this climatic factor on litter production during the studied period.

Table 2. Values of Pearson correlation coefficients between monthly litter production (total and fractions) and the meteorological variables from june 2016 to may 2017.

Tabela 2. Valores dos coeficientes de correlação de Pearson entre a produção mensal de serapilheira (total e frações) e as variáveis meteorológicas no período de junho de 2016 a maio de 2017.

\begin{tabular}{ccccc}
\hline Variables & Leaves & Branches & Reproductive material & Litter \\
\hline Precipitation & $-0.68^{*}$ & -0.05 & -0.42 & $-0.68^{*}$ \\
Temperature & -0.42 & -0.07 & 0.49 & -0.37 \\
Relative air humidity & $-0.74 * *$ & -0.28 & $-0.69 *$ & $-0.78^{* *}$ \\
\hline
\end{tabular}

*significant at $5 \%$ probability; **significant at $1 \%$ probability.

Table 3 shows the adjusted models for the different litter fractions, where the association with the independent variables (Precipitation, Temperature and Relative humidity air) explains the litter production in this area of Cerrado sensu stricto, with an acceptable degree of reliability. $\mathrm{R}^{2}$ aj values range from 0 to 1 , the closer to 1 , the more reliable the model for explanation of litter production will become. Taking into account the isolated $\mathrm{R}^{2} \mathrm{aj}$ values and the Syx\% values, the best models were for leaf fraction and total litter.

Table 3. Models adjusted between the production of litter (fractions and total) and the meteorological variables. Tabela 3. Modelos ajustados entre a produção de serapilheira (frações e total) e as variáveis meteorológicas.

\begin{tabular}{llll}
\hline Variables & Models & $\mathbf{R}^{\mathbf{2}_{\mathbf{a j}}}$ & $\mathbf{S}_{\mathbf{y x}} \%$ \\
\hline Leaves & $8696.09-1.09 . \mathrm{mm}-250.49$. Temp - 22.65.UR & 0.96 & $22.56 \%$ \\
M.R. & $-143.63+10.65$. Temp - 1.67.UR & 0.50 & $84.93 \%$ \\
Litter & $8901.98-0.91 . \mathrm{mm}-243.99 . T e m p-26.88 . U R$ & 0.95 & $22.59 \%$
\end{tabular}

Legend: M.R: Reproductive material; mm: Precipitation; Temp: Temperature; UR: Relative air humidity; $\mathrm{R}^{2}{ }_{\mathrm{aj}}$ : Adjusted coefficient of determination; $\mathrm{S}_{\mathrm{yx} \%}$ : Estimate pattern error in percentage.

\section{Rate of litter decomposition}

The litter decomposition rate was evaluated for nine months (273 days), obtaining a total decomposition of $49 \%$ (leaves) and $50 \%$ (branches). The values of the Pearson correlation coefficient (r) are presented in Table 4 , showing the influence of temperature and relative air humidity on the speed of leaf decomposition $(\mathrm{r}=-0.56$; $r=0.50$ and $p<0.05)$ and the temperature on the decomposition of the branches $(r=-0.66)$. In this way the use of the correlation was a good indicator to determine the meteorological variables that influence decomposition speed.

Table 4. Pearson ( $r$ ) correlation results between the decomposed mass.

Tabela 4. Resultados da correlação de Pearson ( $r$ entre a massa decomposta.

\begin{tabular}{llll}
\hline Variable & Temperature & Relative air humidity & Precipitation \\
\hline Leaves & $-0.56^{*}$ & $0.50 *$ & -0.13 \\
Branches & $-0.66^{*}$ & 0.55 & -0.05 \\
\hline *Significant correlation 5\% probability. & &
\end{tabular}

The exponential mathematical model that describes the leaf decomposition rate is represented by $\mathrm{y}=20.863 \mathrm{e}^{-0,003 x}$, with a regression index of 0.97 and the model for the decomposition of branches by $y=19.674 \mathrm{e}^{-}$ $0,003 x$, with regression index of 0.94 and significance at $5 \%$ (Figure 2). The decomposition constant (k) for both leaf mass and branches had a value of $0.0030 \mathrm{~g} \cdot \mathrm{g}^{-1} \cdot \mathrm{day}^{-1}$. The time for total decomposition ( $\left.\mathrm{t}_{95}\right)$ for both was around 1,000 days (29 months). 


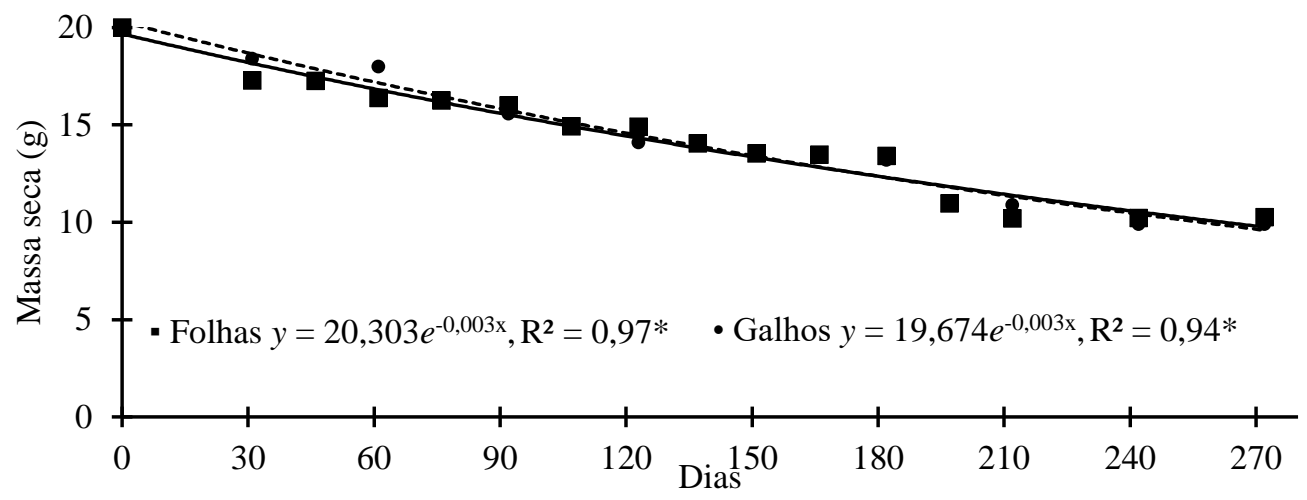

Figure 2. Decomposition curve of leaf and branches biomass in Cerrado sensu stricto area. * significant at 5\% probability.

Figura 2. Curva de decomposição da biomassa foliar e de galhos na área de Cerrado sensu stricto. * significativo a $5 \%$ de probabilidade.

The exponential model was tested for rate estimation, thus obtaining the decomposition constant $(\mathrm{k})$ that for both leaf mass and branches had a value of $0.0030 \mathrm{~g}^{\mathrm{g}} \mathrm{g}^{-1} \cdot \mathrm{day}^{-1}\left(\mathrm{R}^{2}=0.93 ; 0.97 ; \mathrm{p}<0.05\right)$, the total mass disappearance time was around 1,000 days (29 months).

\section{DISCUSSION}

\section{Litter production}

The results of litter production presented in Table 1 are similar to those observed by Brasil et al. (2013) and Cianciaruso et al. (2006), in a fragment of cerradão, where they obtained an annual production of 6,724.44 $\mathrm{kg} \cdot \mathrm{ha}^{-1} \cdot \mathrm{a}^{-1}$ and 5.646.9 $\mathrm{kg} \cdot \mathrm{ha}^{-1} \cdot \mathrm{a}^{-1}$, respectively, both works having greater contribution in the total amount of litter from the leaf fraction. In contrast, Campos et al. (2008), studying two different physiognomies of the Cerrado in Uberlândia (state of Minas Gerais), they found 3,711 kg.ha $\mathrm{a}^{-1} \cdot \mathrm{a}^{-1}$ for Mesophytic Forest and $857 \mathrm{~kg} \cdot \mathrm{ha}^{-1} \cdot \mathrm{a}^{-1}$ for the Cerrado sensu stricto in which these lower values of accumulation may be associated with the lower number of collections, concentrated in the months july to january (seven months), and the different climatic characteristic conditions of the region.

The leaves constituted the largest component of the total litter corresponding to $77 \%$, with the branches representing $18 \%$ and reproductive materials 5\%. According to Calvi et al. (2009), leaves generally form the largest amount of litter biomass, ranging from $60 \%$ to $80 \%$, while the branches (woody and tree parts) present about $1 \%$ to $25 \%$ of the total.

Several authors report in their work that the leaves represent the highest percentage in the formation of litter in tropical forests (MAMAN et al., 2007; SILVA et al., 2007; SANCHES et al., 2009). However, the magnitude of this contribution depends mainly on the species, site structure and age of the trees, since the leaf fraction is in constant productivity, because of the changes resulting from high photosynthetic rates, different phenologies between the local species and the more environmental changes (SILVA et al., 2007). Also, the greater accumulation of leaves in forests may also be a consequence of the rapid growth and foliar renewal of pioneer species.

Many environmental factors interfere with leaf fall, such as: advanced age of leaves, water stress, decreased nutrient uptake, changes in the decomposition of atmospheric gases and consumption by parasitic organisms. In this context, high litter deposition occurred in the months of july with production of $1,464.00 \mathrm{~kg}$.ha${ }^{1}$ and august with $1,185.30 \mathrm{~kg} \cdot \mathrm{ha}^{-1}$, thus indicating a high production during the dry season.

However, there was a considerable reduction of litter accumulation in october (beginning of the rainy season) with subsequent gradual reduction until February, which coincided with the rainy season. The low productivity of litter at this time is influenced by the microbial activity of the soil due to the increase of humidity and also due to the accelerated process of decomposition and mineralization of the organic material.

According to Silva et al. (2007), the occurrence of a high production of litter in the dry season is influenced mainly by water stress, being a response of the vegetation, since the leaf fall reduces the loss of water by transpiration. According to Valentine (2004), the accumulation of litter in the soil is also regulated by the 
amount of material that falls from the aerial part of the plants and by its rate of decomposition, which enriches the soil as the decomposition processes occur.

The leaves are fundamental in the processes of photosynthesis and vegetal transpiration, processes that demand great amount of water. Thus, in the dry season, the plants lose their leaves as an adaptative mechanism to the water stress they are subjected, and, therefore, in the end of the dry season and in the beginning of the rains it is the time that occurs the massive development of the new leaves in tropical forests (COSTA et al., 2007; SANTANA; SOUTO, 2011).

The branches fraction reached the highest production in october, with $164.80 \mathrm{~kg} \cdot \mathrm{ha}^{-1} \cdot \mathrm{month}^{-1}$ and, according to Santana and Souto (2011), the branches fraction reaches higher productivity at the beginning of the humid season. This dynamic is related to the mechanical effect of rain on the deciduous process of the dry branches during the dry season, being easily released by the action of rainwater and wind.

The production of reproductive material was continuous, with a high production in the month of september $\left(98.2 \mathrm{~kg} \cdot \mathrm{ha}^{-1} \cdot \mathrm{month}^{-1}\right)$. This occurs because Cerrado has early and late species bearing fruit almost every month of the year. Still, according to Oliveira (2008), the reproductive phenological patterns of woody plants of Cerrado are less dependent on the seasonal constraints imposed by temperature.

Foi observada correlação negativa significativa entre a produção de serapilheira e suas frações com a precipitação pluviométrica e umidade relativa do ar. Silva et al. (2007) obtained a high correlation between litter and precipitation $(\mathrm{r}=-0.81)$, indicating that there was more monthly deposition in the dry season than in the wet season. Sanches et al. (2009), in a transition region between humid tropical forest and Cerrado, verified that the production occurs seasonally and with significative influence of air relative humidity $(\mathrm{r}=-0.51)$ and precipitation $(\mathrm{r}=-0.53)$ with higher yields during the dry season, as also observed in this research.

Pires et al. in a similar study presented adjusted regression models for litter of their fractions, the temperature being the only variable with significant effect for the estimation of the total litter variables $\left(\mathrm{R}^{2}=0.37\right)$, leaf fraction $\left(R^{2}=0.34\right)$, reproductive fraction $\left(R^{2}=0.54\right)$ and miscellaneous $\left(R^{2}=0.64\right)$. However, for fraction branches, all climatic variables analyzed were significant, with a $\mathrm{R}^{2}=0.76$.

\section{Decomposition rate}

After nine months of the experiment a total decomposition of $49 \%$ (leaves) and $50 \%$ (branches) was obtained. Maman et al. (2007), in a study on nutrient cycling in two Cerrado phytophysiognomies, observed leaf mass decomposition of $59.5 \%$ in Cerradão and $78 \%$ in Gallery Forest in a period of 11 months, with a more intense loss of leaf mass during the rainy season. In another similar study, Cianciaruso et al. (2006) in a Cerradão verified at the end of one year a rate of $43 \%$ of the decomposed mass. Terror et al. (2010) observed, in a paludal forest, a loss of leaf mass of $36 \%$ during a period of 170 days during the dry season. Silva et al. (2014) verified different decomposition percentuals at the end of 6 months of study in three adjacent forest systems: jackfruit plantation $(50 \%)$, native planting (34\%) and native forest (35\%).

There is considerable variation in litter decomposition rate among tropical forests, due to the influence of several environmental factors such as: vegetation cover type, material quality, soil microbial activity, environmental conditions (temperature and humidity), water availability and soil characteristics (CALVI et al., 2009).

The values of the Pearson correlation coefficient presented in Table 4, showed the influence of temperature and relative air humidity on the speed of leaf decomposition and the temperature on the decomposition of the branches. During the rainy season the decomposition occurred with greater intensity due to the fact that litter bags were installed in the month of october, being the beginning of the rainy season, the highest precipitation index and the humidity of this time may have influenced the process of leaf decomposition, this relationship was also found by Silva and Finamore, (2015). With the beginning of the drought the process of decomposition became slower, this can be attributed to the smaller precipitations creating conditions able to restrict the activity of the decomposing organisms. According to Terror et al. (2011), litter degradation is usually favored by increased soil moisture, accelerating the decomposition process, while the water deficit slows down the rate at which the litter accumulated on the soil is decomposed.

According to Sanches et al. (2009) the rapid decomposition occurs initially with the labile material and later in a slower process of more resistant materials. This slow decomposition may be due to the mechanism of adsorption, to the stabilization of metabolites and to the fall of biomass in the soil.

In this research, the constant $(\mathrm{k})$ for both leaf mass and branches was 0.0030. Cunha Neto et al. (2013) verified the decomposition rate $(\mathrm{k})$ closest to that observed in three of the four forest formations evaluated: acacia $(\mathrm{k}=0.0013)$; secondary forest $(\mathrm{k}=0.0026)$; eucalyptus $(\mathrm{k}=0.0028)$; and mimosa $(\mathrm{k}=0.0034)$. Silva et al. $(2014)$ found values of $\mathrm{k}$ varying between 0.0019 and 0.0033 in three adjacent forest systems: native planting, native forest and jackfruit planting. In a study carried out in two physiognomies of the Cerrado in Pirapitinga, state of 
Minas Gerais, Giácomo et al. (2012) found constant decomposition speed (k) for mesophytic forest and for Cerradão of respectively 0.0043 and 0.0040. In the same way Menezes et al. (2010), in Pinheiral (state of Rio de Janeiro) obseved fast decomposition in three forests with different successional stages: secondary forest initial stage $(\mathrm{k}=0.0044)$; secondary forest mean stadium $(\mathrm{k}=0.0038)$; and secondary forest advanced stage $(\mathrm{k}=0.0064)$. In seasonal tropical forests, such as Amazonian ecosystems, mesophilic and Cerrado forests, during the rainy season there is a lower accumulation of litter due to the high activity of decomposing organisms, both from micro decomposers and, mainly, arthropods that remove the litter, becoming the main decomposing agents in the soil; forests of temperate regions and with lower temperature present greater production of litter in the humid season, typical of the Atlantic forests and sand banks. Similarly, it occurs with the water deficit, directly influencing the litter productivity, causing a reduction in the rate of degradation of the organic material deposited on the soil (CIANCIARUSO et al., 2006; PIRES et al., 2006).

\section{CONCLUSIONS}

- The litter production had a well defined seasonality, with a higher production during the dry season and lower production during the rainy season, regarding the contribution to litter production, the leaf fraction was more expressive, followed by the fraction of branches (bark and branches) and finally by reproductive material.

- Through analysis of Pearson correlation and regression it was observed that the meteorological conditions influenced the deposition of leaves, reproductive material and total litter.

- Leaf mass decomposition reached $49 \%$ and that of 50\% in branches, in which the temperature and air relative humidity influenced decomposition rate. In this way, the decomposition showed to be slow as much for the leaves as for the branches, thus obtaining constant decomposition value of $0.0030 \mathrm{~g} \cdot \mathrm{g}^{-1}$. day ${ }^{-1}$ for both.

- The information obtained in the present study can be used as reference to other future works, taking into account the needs of further research to understand the dynamics of litter production in the Cerrado biome.

\section{REFERENCES}

BRASIL, L.S.; GIEHL, N.F.S.; SANTOS, J.O.; SANTOS, A.O.S.; MARIMON, B.S.; MARIMOM JUNIOR, B.H. Efeito de borda sobre a camada de serapilheira em área de cerradão no leste de Mato Grosso. Revista Biotemas, v. 26, n. 3, p.37 - 47, 2013.

CALDEIRA, M. V. W. Biomassa e nutrientes da serapilheira em diferentes coberturas florestais. Comunicata Scientiae, v. 4, n. 2, p. 111 - 119, 2013.

CALDEIRA, M.V.W.; VITORINO, M.D.; SCHAADT, S.S.; MORAES, E.; BALBINOT, R. Quantificação de serapilheira e de nutrientes em uma Floresta Ombrófila Densa. Semina: Ciências Agrárias, v. 29, n. 1, p. 53 - 68 , 2008.

CALVI, G.P.; PEREIRA, M.G.; JÚNIOR, A.E. Produção de serapilheira e aporte de nutrientes em áreas de floresta atlântica em Santa Maria de Jetibá, ES. Ciência Florestal, v. 19, n. 2, p. 131 - 138, 2009.

CAMPOS, E.H.; ALVES, R.R.; SERATO, D.S. RODRIGUES, G.S.S.C.; RODRIGUES, S.C. Acúmulo de serapilheira em fragmentos de Mata Mesofítica de Cerrado stricto senso em Uberlândia-MG. Revista Sociedade \& Natureza, v. 20, n. 1, p. 189 - 203, 2008.

CAMPOLINA, B.; BARROS, M.A.; RUSSO, B.; MARTINS, A.; BURIN, R.H.; BORGES, R.S.T.; VERGARA, R.M.O.; LIMA, P.F.A.; NUNES, A.S.O.; SOUSA, P.A.B.; PEREIRA, E.Q. Secretaria de Planejamento e da Modernização da Gestão Pública (Seplan). Diretoria Geral de Pesquisa e Zoneamento Ecológico-Econômico. Diretoria de Zoneamento Ecológico-Econômico (DZE). Projeto de Desenvolvimento Regional Sustentável. Estudo da Dinâmica da Cobertura e Uso da Terra do Estado do Tocantins. Dinâmica do Tocantins. Palmas: Seplan/DZE, 264 p, 2012.

CIANCIARUSO, A.V.; PIRES, J.S.R.; DELITTI, W.B.C.; SILVA, E.F.L. Produção de serapilheira e decomposição do material foliar em um cerradão na Estação Ecológica de Jatai, município de Luiz Antônio, SP, Brasil. Acta Botânica Brasílica, v. 20, n. 1, p. 49 - 59, 2006.

COSTA, K. C. P. Estoques de biomassa e nutrientes em três espécies de Parkia em plantios jovens sobre área degradada na Amazônia Central. Floresta, v. 44, n. 4, p.637 - 646, 2014. 
COSTA, C. C. A.; SOUZA, A. M.; SILVA, N. F.; CAMACHO, R. G. V.; DANTAS, I. M. Produção de serapilheira na Caatinga da Floresta Nacional do Açú-RN. Revista Brasileira de Biociências, v. 5, p. 246 - 248, 2007.

CUNHA NETO, F. V.; LELES, P. S. S.; PEREIRA, M. G.; BELlUMATH, V. G.; ALONSO, J. M. Acúmulo e decomposição da serapilheira em quatro formações florestais. Revista Ciência Florestal, v. 23, n. 3, p. 379 - 387 , 2013.

GIÁCOMO, R. G.; PEREIRA, M. G.; MACHADO, D. L. Aporte e decomposição de serapilheira em áreas de Cerradão e Mata Mesofítica na Estação Ecológica de Pirapitinga-MG. Ciência Florestal, v.22, n.4, p.669 - 680 , 2012.

LIMA, R. P.; FERNANDES, M. M.; FERNANDES, M. R. M.; MATRICARDI, E.A.T. Aporte e decomposição da serapilheira na Caatinga no sul do Piauí. Floresta e Ambiente, v. 22, n. 1, p. 42 - 49, 2015.

LONGHI, S. J.; CHAMI, L. B.; WATZLAWICK, L. F.; EBLING, A. A. Produção de serapilheira e retorno de macronutrientes em três grupos florísticos de uma floresta ombrófila mista, RS. Ciência Florestal, v. 21, n. 4, p. $699-710,2011$.

MAMAN, A. P.; SILVA, C. J.; SGUAREZI, E. M.; BLEICH, M. E. Produção e acúmulo de serapilheira e decomposição foliar em Mata de Galeria e Cerradão no sudoeste de Mato Grosso. Revista de Ciências AgroAmbientais, v.5, n. 1, p.71 - 84, 2007.

MENEZES, C. E. G.; PEREIRA, M. G.; CORREIA, M. E. F.; ANJOS, L. H. C. PAULA, R. R.; SOUZA, M. E. Aporte e decomposição da serapilheira e produção de biomassa radicular em florestas com diferentes estágios sucessionais em Pinheiral, RJ. Revista Ciência Florestal, v. 20, n. 3, p. 439 - 452, 2010.

OLIVEIRA, P. E. Fenologia e biologia reprodutiva das espécies de cerrado. In: S.M. Sano, S.P. Almeida e J.F. Ribeiro (eds.). Cerrado: ecologia e flora. Brasília, EMBRAPA, p. 275 - 290, 2008.

PIRES, L. A.; BRITEZ, R. M.; MARTEL, G.; PAGANO, S. N. Produção, acúmulo e decomposição da serapilheira em uma restinga da Ilha do Mel, Paranaguá, PR, Brasil. Acta Botânica Brasílica, v. 20, n. 1, p. 173 - $184,2006$.

SANTANA, J. A. S.; SOUTO, J. S. Produção de serapilheira na Caatinga da região semi-árida do Rio Grande do Norte, Brasil. Idesia, v. 29, n. 29, p. 87 - 94, 2011.

SANTOS, H. G.; ALMEIDA, J. A.; OLIVEIRA, J. B.; LUMBRERAS, J. F.; DOS-ANJOS, L. H. C.; COELHO, M. R.; JACOMINE, P. K. T.; CUNHA, T. J. F.; OLIVEIRA, V. A. Sistema brasileiro de classificação de solos. Brasília: Embrapa, p. 253, 2013.

SANCHES, L.; VALENTINI, C. M. A.; BIUDES, M. C.; NOGUEIRA, J. J. Dinâmica sazonal da produção e decomposição de serapilheira em floresta tropical de transição. Revista Brasileira de Engenharia Agrícola e Ambiental, v. 13, n. 2, p. 183 - 189, 2009.

SILVA, C. J. DA.; SANCHES, L.; BLEICH, M. E.; LOBO, F. de A.; NOGUEIRA, J. de S. Produção de serrapilheira no Cerrado e Floresta de Transição Amazônia-Cerrado do Centro-Oeste Brasileiro. Acta Amazônica, Manaus, v. 37, n. 4, p. 543 - 548, 2007.

SILVA, D. R. S.V.; FINAMORE, W. L. M. Velocidade da decomposição e teores de nutrientes de diferentes adubos verdes. A Revista Eletrônica da Faculdade de Ciências Exatas e da Terra. Produção/construção e tecnologia, v. 4, n. 7, p.18 - 27, 2015.

SILVA, H, F.; BARRETO, P. A. B.; SOUSA, G. T. O.; AZEVEDO, G. B.; RODRIGUES, E. F. G.; OLIVEIRA, F. G. R. B. Decomposição de serapilheira foliar em três sistemas florestais no Sudeste da Bahia. Revista Brasileira, Biociências, Porto Alegre, v. 12, n. 3, p.164 - 172, 2014.

TÉO, S. J.; MACHADO, S. A.; REISSMANN, C. B.; FIGUEIREDO FILHO, A. Micronutrientes da biomassa aérea de bracatinga sob diferentes classes de sítio, idade e diâmetro. Floresta, v. 40, n. 4, p. 861 - 870, 2010.

TERROR, V. L.; SOUSA, H. C.; KOSOVITS, A. R. Produção, decomposição e qualidade nutricional da serapilheira foliar em uma floresta paludosa de altitude. Acta Botânica Brasílica, v. 25, n. 1, p. 113 - $121,2011$.

VALENTI, M. V.; CIANCIARUSO, M. V.; BATALHA, M. A. Seasonality of litterfall and leaf decomposition in a Cerrado site. Brazilian Journal of Biology, v. 68, n. 3, p. 459 - 465, 2008. 
